\title{
Textual Analysis: Rhetoric In The Matatu Register In Nairobi Town, Kenya
}

\author{
David Kihara \\ Mount Kenya University, School of Social Sciences \\ Email:dkihara@mku.ac.ke
}

\section{Doi:10.5901/mjss.2015.v6n2s1p354}

\begin{abstract}
The main aim of this research was to analyze language in the communication between the matatu crew and the passengers. The study analyzed texts in the matatu register in the context of communication. The matatu service is vital to the passengers as it speeds up travel. It is therefore essential to understand language use in this register to understand how the participants communicate. An analysis of the matatu register in Swahili has not been carried out. Some scholars, for example Mbugua (2003), have studied the matatu culture from a sociological perspective. So far the researcher has not come across a linguistic analysis of this register. Such an analysis serves to provide the knowledge required to bring together the phonological, grammatical and lexical aspects to make communication effective.
\end{abstract}

Keywords: Analysis, Culture, Linguistics, Language, Communication

\section{Background}

Textual analysis is an analysis of how different sentences in an utterance are related in terms of coherence and cohesion (See Wendell 1992). This is a study of how the rules of a language work through textuality. Textual analysis is the study of language in use. On one hand linguists study the rules that govern a language system while those who carry out textual analysis study how language use is dependent on the context of communication.

These views are commensurate to those of Halliday (1964) who posits language grows not in a vacuum but through the community experiences not in a vacuum and at the same instance acquires its basis, appearance and pattern. The greatest function of language as a communal act is its use as an act of communication among the members of a community. An utterance cannot be properly understood if interpreted on its own without associating it with the many aspects of context and state of the participants, their knowledge, how they relate to one another, the topic, the field and branch of study, the environment and other constraints on communication. This study will put such factors in perspective because the matatu rhetoric is only understood in relation to the context of communication.

The matatu crew and passengers usually communicate in Kiswahili. The style of communication has exhibited a new register in the use of Swahili in the matatu industry. This register has features such as code mixing, use of rhetorical tropes, questions, word adaptation and the effect of Sheng and other native languages like Kikuyu and Dholuo. This study examines how these and other factors affect communication in the matatu sector that is essential in public transport.

\section{Theoretical Framework}

This study was guided by functional linguistics theory. The approach used was that of Systemic Functional Grammar. According to Halliday $(1985,1994)$, Systemic Functional Grammar treats language as a network of meaning. This network is presented through grammatical texts. The smallest text used as a unit of analysis is the clause. The clause is equivalent to a simple sentence. Systemic Functional Grammar identifies and involves three branches of grammar: Syntax, Semantics and Pragmatics.

In this approach, syntax involves the relationship between the forms. Syntax identifies the state and status of the forms in the text. Terminologies in the field of syntax are such as subject and object. Pragmatics looks at the value of utterances in relation to the wider context of language and communication. Examples of concepts in pragmatics are themes and inference. In short, pragmatics studies language as a system of meaning in the context of communication.

Systemic Functional Grammar looks at a text and the way it meets the needs of communicative competence and pragmatic adequacy. Language is a pragmatic sign, a sign to enable communication, where pragmatics dictates 
semantics and semantics in turn dictates syntax. Due to these relations, language cannot be understood fully if pragmatics is overlooked. By putting this in account, Systemic Functional Grammar has identified three types of meaning: conceptual, interpersonal and textual meaning.

Conceptual meaning is also known as cognitive meaning. It is the aspect of meaning that represents the speaker's ability to distinguish things. This type of meaning carries the content in language. Through conceptual meaning, language encodes cultural and social experience while the speaker encodes his personal experience. It's through conceptual meaning that we get the information and knowledge of the world we live in and represent our experience too. Conceptual meaning is a means to understand and explicate information and knowledge in general. It is qualified through interpersonal meaning.

Interpersonal meaning is social meaning, and in a wider sense associative meaning. It represents the interactional aspect of language use as dictated by societal conventions. It aids the language users to construe and translate the function and purpose of language. Through interpersonal meaning the speakers use the language to initiate, nurture and sustain the conditions of social relations. The utilization of interpersonal meaning depends on the societal functions and relations.

Interpersonal meaning is a functional resource of language. Functional resource defines language use as a speech act. The speaker is an actor who participates in this act. It means that the speaker participates in the speech act, participates in the context and actual act of communication so as to express himself and be understood.

Together, conceptual meaning and interpersonal meaning makes use of the universal rules of language use, which is to control our environment and use our intelligence. These claims indicate that every language in the world is constituted with two basic types of meanings: conceptual and interpersonal meanings. Conceptual meaning deals with the truth of the expression while interpersonal meaning looks at the rules of overall communication and societal conventions. These are the basic resources. The representation of the two basic functions of language depends on the third resource: textual meaning.

Textual meaning refers to all the rules of grammar and clarity of linguistic communication. This means textual meaning guides language use; it provides the speaker with the means to relay information in a grammatical and clear manner according to the contextual constrains and communication situation.

So textual meaning performs the function of conveying. However it will be through the collaboration with conceptual meaning on one hand and interpersonal meaning on the other hand that textual meaning will adequately convey information as intended. Systemic Functional Grammar (SFG) prides itself on linguistic accuracy.

Other than linguistic accuracy, SFG lays a claim to pragmatic as well as psychological practicality. The harmony between these aspects is the basis of implicature. According to Malmakjer (1991), Grice 1975 has used the terminology of implicature to refer to what the speaker might be conveying other than what he has explicitly stated. There are two types of implicatures: conventional implicatures and conversational implicatures.

Conventional implicatures are the meaning of words as expressed conventionally. A person doing a pragmatic textual analysis will be more concerned with conversational implicatures. Conversational implicatures arise from the cooperative principle that has maxims that are observed by the speakers. Through the cooperative principle it is possible to see how additional meaning is derived from what people say by putting into consideration the fact that people know not just the expression in their language but also the knowledge and general rationality to understand the meaning of the utterances.

The cooperative principle has been used to explain how people realize the meaning of an utterance. It states: Make your conversational contribution such as is required, at the stage at which it occurs, by the accepted purpose or direction of the talk exchange in which you are engaged. This means that the intended meaning is explicit when an utterance is bound together by maxims of cooperation: the maxims of quantity, quality, manner and relation.

The maxim of quality requires the participant to make his contribution as informative as required for the recipient to understand. That is, the participant should make his contribution for the current purposes of the exchange. He should not make his contribution more informative than is required. This tenet clarified the amount of information that the matatu crew and passengers required to communicate. They are supposed to ensure its lengthy enough to communicate. For example:

Tout: Hamsini (fifty bob) Bus Station.

Passenger: Kimbo ngapi? (How much fare to Kimbo?)

Tout: Kumi, kalia twende mama. (Ten bob, get in we go)

In this conversation, the crew and the passenger give the amount of information required to communicate. 
The quality maxim requires a participant in communication to make a contribution which is true and that can be substantiated without any intention to mislead. The participant should not say what he believes to be false and that which he lacks adequate evidence. This maxim insists on the concept of truth in communication and truth is an important component that makes the speakers intention be clear. This tenet helped us understand how the matatu tout is expected to give truthful information to enable the passengers understand their intention. For example:

Tout: Kumi Utalii, thirty Commercial (fare is ten bob to Utalii stage and thirty bob to Commercial stage).

Passenger: Wapita Commercial? (Are going via Commercial stage?)

Tout: Ndio Dadi, angalia mbao ni fourty four. (Yes man, check the sign; it states this is a route 44 matatu)

In this example, the truth of the tout's utterance is proved by the sign at the front of the matatu which shows which route the matatu plies. The passenger gets to confirm the truth through the sign.

The maxim of manner requires the participant to avoid obscurity of expression as well as ambiguity. He should not vaunt or be garrulous, he should be brief, be orderly and polite. This maxim looks at how a speaker organizes his utterance so that his intention is clear. Avoiding ambiguity, being brief and truthful are key aspects that contribute to the understanding of the intention of the speaker but depends on the context. This tenet helped us understand how the matatu tout avoid ambiguity in order to communicate properly with the passengers. For example:

Tout: Dandora mbao, Huruma na Mathare kumi. (fare is twenty bob to Dandora and ten bob to Huruma as well as Mathare)

This example clearly shows that the tout's utterance has no ambiguity whatsoever. Every passenger will understand that the fare to Dandora is twenty shillings and that to Huruma and Mathare, one will pay ten shillings for fare.

The maxim of relation requires the participant to say things that are pertinent to the discussion. His points should be relevant to the discussion. This tenet helped us explain how the speaker (matatu crew) uses language to identify himself and build a relationship with his listeners (passengers). For example:

Tout: Pesa mbele. (Fare at the front)

Passenger: Leta 'change' yangu. (I need my change)

The passenger's statement in this conversation is pertinent to the topic of conversation. He had already paid the fare and was not given his change so he decides to ask before the tout finishes collecting fare from the other passengers.

In an analysis of cooperation maxims a text is considered a speech act. Linguists who described language as a communicative act are Yule 1996, Levinson 1983, Collinge 1990, Malmakjer 1991, Trauth and Kazzazi 1996. These linguists explain that communication is an act carried out at the production of an utterance where stating something is the same as acting. Its what people do with words that they utter. Every utterance brings about an act. These views will be expounded on in the literature review.

\section{The Features of the Matatu Register}

\subsection{Code Mixing}

Code mixing has been defined linguistically as the insertion of words or parts of words from another language in an utterance that is in a different language. (Cf: Richards et al 1985, Saville-Troike 1989, Deuchar 2000 and Lanza 2004). Scholars such as Fasold (1984) and Milroy (1987) have explained the difference between code mixing and code switching. However, in this section we will address code mixing as defined by Pfaaff 1979 as quoted by Lanza (2004).

According to this study the languages that are usually mixed are Swahili and English, although sometimes people code mix using their native languages. The analysis identified three types of code mixing:

- Word(s) insertion at the beginning of an utterance or initial insertion.

- Word(s) insertion in the middle of an utterance or medial insertion.

- Word(s) insertion at the end of an utterance or terminal insertion.

Word(s) insertion at the beginning of an utterance is the process of cod mixing which is prevalent in the data collected as exemplified in this table: 


\begin{tabular}{|c|c|c|}
\hline Word(s) inserted & Origin of word(s) & Statement in target language \\
\hline Faster faster & English & Faster faster kushuka. \\
\hline Thirty bob & English & Thirty bob ingia. \\
\hline Thirty thirty & English & Thirty thirty gari. \\
\hline Twenty six & English & Twenty six ngapi? \\
\hline Change & English & Change yangu? \\
\hline Twenty Allsops & English & Twenty Allsops njiani kumi. \\
\hline Twenty bob & English & Commercial \\
\hline Commercial Commercial & English & Faster kubebana. \\
\hline Faster & English & Commercial Commercial kalia twende. \\
\hline Commercial Commercial & English & Twenty bob gari. \\
\hline Twenty bob & English & Faster kushuka. \\
\hline Faster & English &
\end{tabular}

The word or words in italics were inserted at the beginning of the sentence. All these words are English words. It's apparent that code mixing here involves Swahili and English languages. The English language is held with high esteem so it's is the source language in many instances as illustrated.

Word(s) are also inserted in the middle of a statement where English or Sheng words are inserted in statements in Swahili. This is illustrated in the following table:

\begin{tabular}{|c|c|c|}
\hline Word(s) inserted & Origin of word(s) & Statement in target language \\
\hline Thirty & English & Gari thirty kalia twende wewe. \\
\hline Chassis & English & Hiyo chassis haiwakosi kila wakati huwa masaa ya pesa. \\
\hline Line & English & Omba line upande wako. \\
\hline Stage & English & Hii gari inakaa kwa stage sana. \\
\hline Twenty six & English & Funga gate haraka. \\
\hline Gate & English & Hamsini Thika, Muthaiga na Survey kumi. \\
\hline Survey & English & Wawili wawili Commercial Nairobi hapa. \\
\hline Commercial & English & Gari thirty bob kalia. \\
\hline Thirty bob & English & Maringo twenty bob njiani kumi. \\
\hline Twenty bob & English & Wee Roundaa bwana. \\
\hline Roundaa & Sheng & Eeh pamoja na Technical kalia. \\
\hline Technical & English &
\end{tabular}

In this table the word(s) written in italics have been inserted in the middle of an utterance. These are English and Sheng words. The word roundaa which is a Sheng word adapted from the English word round-about. In Sheng, the word roundaa has been adapted from roundabout by lengthening the vowel [a:] to compensate for the loss of the ultimate syllable. Code mixing in this case involves Swahili, English and Sheng.

Insertion of words at the end of a statement occurs when English forms are inserted at the end of an utterance in Swahili as this table shows:

\begin{tabular}{|c|c|c|}
\hline Inserted word(s) & Word(s) origin & Statement in target language \\
\hline Garage & English & Una mtu wa Garage? \\
\hline Phase one & English & Tuzikae mbele Phase one. \\
\hline Thirty two & English & Chunga hiyo thirty two. \\
\hline Jam & English & Wacha nishuke na jam. \\
\hline College & English & Kuna College? \\
\hline Boss & English & Ni kumi kalia Boss. \\
\hline Town & English & Kumini kalia town. \\
\hline Mamii & Sheng & Kumi kalia twende antii. \\
\hline Antii & Sheng & Sina wadhii. \\
\hline Wadhii & Sheng & \\
\hline
\end{tabular}

In this table the words written in italics are terminal insertions. They are English and Sheng words. Sheng words are mamii, antii and wadhii. Mamii is an adaptation of the English word mammy meaning mother. Antii is an adaptation of auntie or aunt. Wadhii has been adapted from a Kikuyu word meaning commuters. Code switching in this instance has 
involved Swahili, English and Sheng.

Two levels of word adaptation have been identified: phonological adaptation as well as morphological adaptation. The process of adaptation from athii to adhii is phonological. The unvoiced fricative / /e/ changes to the voiced fricative / $/$ /. These fricatives are dental consonants because they are produced by touching the upper front teeth with the tip of the tongue. Phonological adaptation occurs as a result of the interaction between two language systems. The change in the word adhii to wadhii is morphological. la/ which is a low and central vowel changes to the syllable /wa/. At this level of adaptation, there are word formation changes, due to the influence of the word structure and order in Swahili language.

Codes mixing in the matatu register shows that the speakers intend to expound on a concept, appeal and identify themselves with the audience.

\subsection{Figures of Speech}

Wamitila (2004), states that a figure of speech is a word or phrase whose meaning is not explicit. Figures of speech are common not only in literary works but also regular communication. Some of the figures of speech found in the data analyzed are:

- Repetition

- Personification

\subsection{Repetition}

According to Wamitila (2004), repetition is a figure of speech where a syllable, word, phrase or sentence is repeated. We therefore have: word repetition, line repetition, vowel repetition and consonant repetition. What is evident here is word repetition. The following tables will show word repetition in terms of:

- Nouns

- Determiners

- Verbs

\begin{tabular}{|c|c|}
\hline Nouns & Utterance \\
\hline Commercial & Commercial Commercial Tusker mwisho. Unaenda? \\
\hline Mbao & Mbao mbao Dandora njia ya ndani hapa. \\
\hline Huruma, John Saga & Chapuma John Saga kumi na tano. Huruma John Saga kumi na tano. \\
\hline Chapaa & Thika. Thika. Kalia Thika hamsini Survey na Allsops mbao. \\
\hline Thika & Ya Ruiru. Ya Ruiru. Ruiru ndani kalia. \\
\hline Ruiru & Pesa. Pesa. Hapo mbele pesa. \\
\hline Pesa & Gikomba Eastleigh. Gikomba Eastleigh. \\
\hline Gikomba, Eastleigh & Commercial, Nairobi. Commercial Nairobi hapa. \\
\hline Commercial, Nairobi & Babadogo. Babadogo kumi. \\
\hline Babadogo & Senti senti. Senti kwa kona. \\
\hline Senti & Maringo Maringo mbao. \\
\hline Maringo &
\end{tabular}

According to Kamusi ya Kiswahili Sanifu; Oxford (2004), a noun is a word that refers to the name of a place, person, object, situation or action. This study has also identified repetition of place names and things such as money, as shown in the following table:

\begin{tabular}{|c|c|}
\hline Determiners & Utterance \\
\hline Wawili & Wawili wawili kalia Nairobi na njiani. \\
\hline Kumi & Kumi kumi ya ndani hadi Phase Four beba. \\
\hline Kumi na tano & Huruma John Saga kumi na tano. Huruma John Saga kumi na tano. \\
\hline Haraka & Shuka haraka haraka ndio wale kalao. \\
\hline Hapo & Vuta mbele kidogo. Vuta tena. Hapo hapo. Ni sawa. Itakula vizuri hapo. \\
\hline Hao & Beba hao. Beba hao. \\
\hline Hiyo & Haraka. Waiona nyuma. Hiyo hiyo. \\
\hline
\end{tabular}

The repetition of determiners is a feature of this register as exemplified in the table above. Determiners in this case 
include numeral adjectives and demonstratives. Besides these types of repetition, there is adverb repetition as shown in the statement shuka haraka haraka ndio wale kalao. According to Mbaabu (1982), an adverb is a word, affix, or group of words that add meaning to a verb, adjective or another adverb within a sentence. An adverb answers questions such as: how did the action take place, in what manner and in what place.

The research has also shown that verb repetition is also featured as shown in the table below. According to Mbaabu (1992), a verb is any word that indicates an action been carried out by a person, animal or anything else.

\begin{tabular}{|c|c|}
\hline Verb & Utterance \\
\hline Faster & Faster faster kushuka. \\
\hline Toa & Toa toa dereva. \\
\hline Beba & Beba beba Kamenu Posta. \\
\hline
\end{tabular}

As shown in the tables, repetition is a figure of speech or stylistic device where words are repeated intentionally to put more emphasis on meaning or put it more clearly. When important word are repeated, it shows the objective by appearing in different segments of discourse.

\subsection{Personification}

According to Swahili scholars (such as Njogu and Chimera 1999, Ngure 2004 and Wamitila 2004) personification is a stylistic device where an inanimate object is endowed with human qualities such as feelings, logic or human intuition. It is a figure of speech used to affect feelings. Examples of personification are shown in the following diagram:

\begin{tabular}{|c|l|l|}
\hline Data & Text & Meaning of data \\
\hline Kula & Gari inakula sasa? (Is the vehicle eating presently ) & Is it being boarded? \\
\hline Hula & $\begin{array}{l}\text { Tulia mama hii hula chapuchapu. Wawili tu twende (Be patient maam, it } \\
{[\text { matatu] eats fast. Two more [passengers] and then we leave) }}\end{array}$ & $\begin{array}{l}\text { lt's is usually boarded [very } \\
\text { quickly]. }\end{array}$ \\
\hline $\begin{array}{c}\text { Kushikwa na } \\
\text { jam }\end{array}$ & Harakisha tushishikwe na jam. (Hurry up lest the jam catches up with us) & To be held up in a traffic jam. \\
\hline
\end{tabular}

In the data presented in the table above, the matatu is personified. Eating is a action performed only by living things such as humans and animals. The vehicle is boarded by passengers; it does not eat (kula). The personification in gani inakula sasa actually means which one is being boarded right now? Hula chapuchapu means it is boarded quickly.

(Traffic) jam is a long line of vehicles that can barely move. It happens for example in the morning when people are heading to work and in the evening when they are going back home. Similarly, it occurs when there is an accident or the road is under construction. It is only living things such as human beings, animals, fish and insects that can get hold of something or someone. The (traffic) jam in this case is personified.

\subsection{The Use of Questions}

Questions have been prevalent in the data collected and analyzed. The Kamusi ya Kiswahili Sanifu ya Oxford (2004,) states that a question is a something of which an answer is sought. Questions have important functions in communication. The asking of questions brings together the two participants in communication. Goody (1978) explains that in an experiment carried out in social psychology, it became apparent that questions are devices that affect the way information is organized and presented. The following table gives examples of questions that were present in the date we analyzed.

\begin{tabular}{|l|l|}
\hline Question & Answer \\
\hline K.U. ngapi? (How much is the fare to K.U?) & Namba nne kalia twende. (Forty bob, get in) \\
\hline Allsopps how much? (How much is it to Allsops?) & Thelathini kalia twende. (Thirty shillings, get in) \\
\hline Unaenda madam? (Are you travelling?) & Eeh. (Yes) \\
\hline $\begin{array}{l}\text { Unabeba Phase one? (Are commuters alighting at Phase } \\
\text { one allowed in?) }\end{array}$ & Kalia bebwa ni kumi madam. (Get in, it's ten shillings) \\
\hline Ati ngapi ? (How much again?) & $\begin{array}{l}\text { Twenty Allsopps njiani kumi. (Ten shillings to Allsops, ten bob for stages } \\
\text { on the way) }\end{array}$ \\
\hline
\end{tabular}




\begin{tabular}{|l|l|}
\hline How much D.C? (How much to D.C?) & Twenty bob huko Maringo kalieni twende. (Twenty bob to Maringo, get in) \\
\hline $\begin{array}{l}\text { Unabeba Ruiru? (Are commuters headed for Ruiru } \\
\text { allowed in?) }\end{array}$ & Eeh. Kalia seventy bob. (Yes. Get in its seventy bob) \\
\hline Wangapi? (How many more?) & Wawili chukua mbele. (Two more passengers, pick them ahead) \\
\hline Wapiti hospitali? (Are you using the hospital route?) & Eeh. Pamoja na Technical kalia. (Yes. Via Technical too) \\
\hline Wamekwisha? (Have the passengers all alighted) & Eeh. Mmoja tu. (Yes, only one remaining) \\
\hline
\end{tabular}

As shown in this table, questions are used by the matatu crew and passengers to communicate. Questions asked require answers. The answer to every question carries the information sought by the person asking the question. Therefore questions are speech acts that bring two people together to relate and also understand each other better.

\subsection{Word Adaptation}

According to the Oxford's Kamusi ya Kiswahili Sanifu (2004), adaptation is changing the structure of a word from a particular language in order to make it conform to the grammar of another language. For example auntie has been adapted to antii (Sheng).

The study has identified two types of word adaptation: phonological and morphological adaptation. The process of adapting athii to adhii, as shown in the following table, is phonological. The unvoiced fricative / / / becomes the voiced fricative /ð/. These fricatives are dental because they are pronounced when the tongue is in between the teeth. The interaction between two language systems brings about phonological adaptation. On the other hand, the change of adhii to wadhii exemplifies morphological adaptation. The vowel /al changes to the syllable /wal. At this level of adaptation, there are word formation changes, due to the influence of the word structure and order in Swahili language.

Word adaptation is one of the word formation processes in Swahili language. We borrow from other languages and cultures, words to enrich our lexicon. Borrowing comes as a result of cultural and social interaction over a long a period of time. In adaptation, the borrowed word acquires the features of the target language, which is Swahili. They undergo swahilification as shown in the following table:

\begin{tabular}{|c|c|c|}
\hline Word & Text & Original word before adaptation \\
\hline Roundaa & Mbao mbao Allsopps, Phase one, Roundaa na Kariobangi kumi. & Round-about (English) \\
\hline Mamii & Kumi kalia mamii. & Mammy (English) \\
\hline Antii & Kumi kalia twende antii. & Auntie (English) \\
\hline Senti & Senti senti. Senti kwa kona. & Cent (English) \\
\hline Kona & Pesa. Pesa kwa kona. & Corner (English). \\
\hline Shilingi & Toa na ubebe watu na shilingi nne ni wengi. & Shilling (English) \\
\hline Hospitali & Wapita hospitali? & Hospital (English) \\
\hline Namba & Watu ni wengi, beba na namba tatu. & Number (English) \\
\hline Wadhii & Sina wadhii. & Athii (Kikuyu) \\
\hline
\end{tabular}

As shown in this table, roundaa is an adaptation from the English word round-about. The word which is used in Sheng is the clipping of the word rounda-about which is a type of circular intersection where different roads meet. Mamii, a Sheng word meaning mother is an adaptation of the English word mammy. Similarly, antii is a Sheng word meaning aunt, adapted from the English word auntie.

Senti is an adaptation of cent; a monetary value equal to $1 / 100$ of the basic unit of value, a Kenyan shilling for example. In Kenya cents were copper coins that are no longer in circulation. Shilingi is an adaptation of shilling which in the East African region is a coin equivalent to 100 cents.

Kona is an adaptation of corner, a secluded area. Namba is adapted from number which is an arithmetic value. Hospitali has been adapted from hospital. The Sheng word wadhii is an adaptation of the Kikuyu word athii meaning travelers. Roundaa, mamii, antii, senti, centi kona shilingi and namba are used in day to day communication. However wadhii is mainly used in the matatu register.

Adaptation has its superfluity. This superfluity is evident when many words with different structure abound after adaptation. Superfluity is a good thing according to the tenets of communication. It conforms to language styles and differences in expression.

\subsection{The use of Sheng}

According to Mbaabu and Nzuga (2003), originally Sheng was thought to be a combination of English and Swahili where 
Swahili contributed SH and combined with ENG from English to form the word Sheng. However Sheng is a mixture of more languages, not just Swahili and English. It derives its lexicon from all languages used in Kenya; African and even European.

There have been claims that Sheng was created by the youth as a code used to communicate amongst themselves. It was used to pass on their secretive messages to ensure grow ups especially their parents were none the wiser. One feature of Sheng is that several words are used to refer to the same signifier. When a word becomes common, it loses its appeal and another is coined to replace it. Sheng is used by young children not yet in school, the youth and the middle aged in several social groups in Kenya. Its use has become widespread, in many sectors such as advertisement and business. For example, it is used in the matatu business by the crew and the passengers as the following table shows:

\begin{tabular}{|c|c|c|}
\hline Data & Text & The meaning of the data \\
\hline Wadhii & Sina wadhii. & Passengers/commuters \\
\hline Tao & Tao, Odeon hadi Tusker mwisho. & Town \\
\hline Chapaa & Chapaa. & Thirty (bob) \\
\hline Selasa & Selasa, ingia twende. & Twenty shillings \\
\hline Mbao & Dandora mbao njia ya ndani bebwa. & Ten shillings \\
\hline Kidy & Kidy moja kalia madam twende. & Conductor \\
\hline Kondaa & We kondaa lete change. & Driver \\
\hline Deree & Kanyangia stage deree. & Police \\
\hline Kalao & Chunga hao kalao. & New currency note, one hundrend shillings \\
\hline Dubai, soo & Nipe hamsa mbili na dubai za soo. & Slowly, smart matatu \\
\hline Mosmos, nganya & Wachana nayo, tutaenda mosmos. Huwezi shindana na nganya. & Stadium \\
\hline Stadium & Buruburu Makandara stadii kalia twende. & Buruburu (an estate ) \\
\hline Buruu & Buruu wewe na Stadium hapa. & Vehicle \\
\hline Dinga & Chunga hizo dinga deree. & Mother (woman) \\
\hline Mathy & Kushuka ni bure. Fanya haraka mathy. & \\
\hline
\end{tabular}

The word wadhii shown in the table above is an adaptation of the Kikuyu word athii which means travelers. Tao is a clipping of the word town. The word chapaa refers to money; the word selasa refers to thirty while mbao is an adaptation of the English word pound, that is twenty shillings.

Kidy, deree, kondaa and kalao are all part of the Sheng lexicon. Kidy refers to ten shillings. Deree is a clip of dereva, a word adapted from driver. Similarly, kondaa is a clip of the word kondakta which is an adaptation of the word conductor. Kalao refers to the police.

The word dubai is used in the matatu register to refer to the new coins in the dominations of five, ten and twenty shillings. These coins acquired this name as they came into use when second hand vehicles started being imported from Dubai to Kenya. Soo refers to one hundred shillings. In the matatu context then dubai ya soo refers to an assortment of the new coins worth a hundrend shillings.

The word nganya is used to refer to smart matatus compared to the other drab ones. This smartness has to do with seats, tyres, lights, the christening and having loud music otherwise known as hewa. Mosmos means slowly and is derived from the Dholuo word mosmos which means going or driving slowly.

Stadii is a clip of stadium and is used in the matatu register to refer to the City Stadium stage which is along Jogoo Road, one of the main roads into the city. Buruu is clipped from Buruburu one of the city estates. Dinga refers to a vehicle. The word mathy is a clip of the English word mother.

Clearly many words used in the Sheng used in the matatu register are acquired through adaptation, clipping and loans from English and African languages such as Kikuyu and Dholuo. This is an indication of the complementary nature of various methods of word formation used in language generally.

\section{Conclusion}

This paper has analysed and identified the various features of matatu register. Five features have been identified: code mixing, figures of speech, use of questions, word adaptation and the use of Sheng. Three types of code mixing have been identified: initial insertion of words, medial insertions as well as terminal ones. Figures of speech that were identified are repetition and personification. Nouns, verbs and determiners were the categories of words repeated. The matatu crew and passengers used questions to communicate. Many of the adapted words were acquired from English and African languages. The matatu Sheng is different from the Sheng used in other sectors. 
We have noted there is the different aspects of one feature complement one another, together with harmony between the different features of matatu register. This harmony of the various aspects of communication is addressed together with the effect of language use in the following chapter.

\section{References}

Aloo, S. 2002. 'Uchanganuzi wa Matangazo ya Redio na Televisheni: Mtazamo wa Kipragmatiki'. Unpublished M.A Research Thesis: Kenyatta University, Nairobi.

Beaugrande, R. and Dressler 1981. Introduction to Text Linguistics. New York: Longman.

Brown, G. and Yule 1983. Discourse Amalysis. Cambridge: Cambridge University Press.

Collinge, N. E. (Ed) 1990. An Encyclopedia of Language. London: Routledge.

Cook, G. 1989. Discourse. New York: Oxford University Press.

Davis, S. and Gillon 2004. Semantics. Oxford: Oxford University Press.

Deuchar, M. 2003. Bilingual Acquisistion: Theoretical Implications of a Case. New York: Oxford University Press.

Dijk, V.T. 1977. Text and Context: Explorations in the Semantics and Pragmatics of Discourse. London: Longman.

Edmondson, W. 1981. Spoken Discourse. London: Longman.

Fasold R. 1984. The Sociolinguistics of Society. Oxford: Basil Blackwell.

Goody, E. N. 1978. Towards a Theory of Questions: Questions and Politeness Strategies in Social Interactions. Cambridge: Cambridge University Press.

Habwe, J.H. 1989. Elements of Pragmatic Discourse among the Mvita People. Unpublished M.A Thesis, University of Nairobi, Nairobi.

Halliday. M.A.K. et al 1964. The Linguistic Science and Language Teaching. London: Longman.

Halliday, M.A.K. 1985. An Introduction to Functional Grammar. London: Edward Arnold.

Halliday, M.A.K. 1994. Functional Grammar $2^{\text {nd }}$ ed. London: Edward Arnold.

Inyani, S.K. 1992. 'Uchambuzi wa Fani katika Utenzi wa Vita vya Wadachi Kutamalaki Mrima'. Unpublished M.A Thesis, Moi University, Eldoret.

Kiai, A.W. 1996. 'A Discourse Analysis of Educational Radio Programs to Farmers Adaptation Register'. Unpublished M.A Thesis, University of Nairobi, Nairobi.

Kitsao, J. 1975. 'A Stylistic Approach Adapted for the Study of Kiswahili Prose Texts. Unpublished M.A Thesis: University of Nairobi, Kenya.

Kitsao, J. 1982. 'An investigation of Themes in Kiswahili Literature: An Application of Stylostatistics to Chosen Texts'. Unpublished PhD Thesis: University of Nairobi.

Lanza, E. 2004. Language Mixing in Infant Bilingualism: A Sociolinguistic Perspective. New York: Oxford University Press.

Levinson S.C. 1983. Pragmatics. Cambridge: Cambridge University Press.

Malmakjear, K. 1991. The Linguistics Encyclopedia. Amsterdam: John Benjamins Publishing Company.

Mbaabu, I. 1992. Sarufi ya Kiswahili. Nairobi : Longman Kenya.

Mbugua, M. 2003. 'Identity Politics in Nairobi Matatu Folkrole'. Unpublished PhD Thesis: Hebrew University of Jerusalem.

Michira, J.N 1993. 'Uchanganuzi wa Kimtindo wa Lugha ya Wachuuzi na Lugha ya Matangazo ya Biashara Redioni'. Unpublished M.A Thesis: University of Nairobi.

Milroy, L. 1987. Observing and Analysing Natural Languages. New York: Basil Blackwell.

Ndung'u V. 2001. 'Uchanganuzi Usemi katika Sajili ya Dini: Sifa Bainifu za Lugha ya Mahubiri'. Unpublished M.A Thesis: Kenyatta University, Nairobi.

Neyole, N.E. 2003. "Umatini katika Vichekesho vya "Redykyulass" '. Unpublished M.A Thesis: Kenyatta University, Nairobi.

Njeri, T. 1997. 'Cohesion and Compactness in Compositions Written by Kenyan Urban Primary School Children'. Unpublished M.A Thesis: Kenyatta University, Nairobi.

Njogu, k. and Chimera 1999. Ufundishaji wa Fasihi: Nadharia na Mbinu. Nairobi: Jomo Kenyatta Foundation.

Njue, J.G. 1989. 'Muwala katika Kiswahili: Umuhimu wake katika Uchambuzi wa Ngano za Waswahili'. Unpublished M.A Thesis: University of Nairobi.

Richards, J. et al 1985. A Longman Dictionary of Applied Linguistics. London: Longman.

Salkie, R. 1995. Text and Discourse Analysis. London: Routledge.

Saville-Troike, M. 1989. The Ethnography of Communication: An Introduction. Oxford: Basil Blackwell.

Trauth, G. and Kazzazi 1996. Routledge Dictionary OF Language and Linguistics. London: Routledge.

TUKI 2004: Kamusi ya Kiswahili Sanifu. Dar es Salaam: Oxford University Press.

Walya, E. 1996. 'Kenya Banking Discourse structure: Strategies' and their Effects on Banking Interaction'. Unpublished M.A Thesis: Kenyatta University.

Wamitila, K. W. 2004. Kichocheo cha Fasihi: Simulizi na Andishi. Nairobi: Focus Books.

Wendell, V.H. 1992. Dictionary of Concepts in Literary Criticism and Theory. New York: Greenwood Press.

Yule, G.N. 1996. Pragmatics. Oxford: Oxford University Press. 